\title{
Suppliers Involvement Strategies in Flex Fuel Vehicle Development
}

\author{
Paulo Tromboni de Souza Nascimento \\ FEA / USP \\ tromboni@usp.br \\ Wilian Gatti Junior \\ FEA / USP \\ wgatti@usp.br \\ Abraham Sin Oih Yu \\ FEA / USP \\ abraoyu@ipt.br \\ Francisco Emílio Baccaro Nigro
Poli / USP
fnigro@sp.gov.br
}

ABSTRACT: The flex-fuel car is a commercial success in Brazil. This innovation illustrates two different strategies of supplier involvement in technology development: black-box and gray-box or codesign. This paper presents two cases studies of how two mature Brazilian automakers subsidiaries (Volkswagen and General Motors) undertook the development of flex-fuel technology. We also present the development's context, which led to the technology wide spread adoption. Then we discuss the possible impact of both involvement strategies on dependence relations between automakers and their module suppliers, suggesting they will not change large trends toward more, even if limited, dependence on complex high technology modules or "systemist" suppliers.

Keywords: bio fuel deployment, co-development, subsidiary innovation, supplier's capabilities, sub systems innovations, ethanol, flex fuel. 


\section{INTRODUCTION}

Until the 1990s, Brazil's automobile industry operated at a serious technological disadvantage compared to the reality experienced by Europeans, Japanese and North Americans. The country's political and economic situation favored a technology lag throughout the industry's productive chain. The following years witnessed tougher competition worldwide, and the internationalization of the Brazilian economy forced the domestic industry to adapt to global standards. New production facilities were installed in the country by already established companies and new entrants. Existing plants were expanded or revamped. The auto parts industry followed suit, and many national groups were acquired by foreign capital investors.

The new managerial paradigm that emerged in this period was clearly inspired in the Japanese industry (Caputo and Zirpoli, 2002), introducing vertical disintegration in the production process and also in the new product development (NPD).

Since 1990, the modernization of the Brazilian industry promoted a number of successful initiatives, including a new technology that dominates today's Brazilian auto market: the flex-fuel system. Despite the economic importance of this development, studies on flex-fuel technology are still limited. There is some historical account of its development (Teixeira, 2005), from the perspective of one of the companies that participated in this process (Sobral et al. 2005) and a view of this technology as a possible local dominant power train technology (Nascimento et al., 2009a).

The present research aims to widen this discussion by presenting the strategies adopted by two of Brazil's major automakers in their efforts to monitor and to select among flex-fuel systems, each with different architectures, that were developed by their suppliers. These strategies resulted in the selection of the same architecture by both automakers, and they launched the first car models within the short span of three months.

\section{LITERATURE REVIEW}

Clark's early work (1989) had shown that the Japanese automakers led more NPD projects and got faster to the market, through the suppliers' involvement in product development at levels above the European and American automakers. Since then, academic research has focused on understanding the relationship between industries and their suppliers, increasingly reporting results in different markets and industries (Johnsen, 2009).

The suppliers involvement in NPD includes the resources they offer (skills, investment, information, knowledge and ideas), the activities they develop and the responsibilities they take on in a project (or part), process or service that benefits buyers in current or future projects (van Echtelt et al., 2008). Among the short-term gains obtained with suppliers' involvement are improvements in product quality and lesser development time and costs. The longterm, permanent, access to new technologies, the alignment of technology strategies with key suppliers, the contributions from one project to other developments and the experience accumulated by the supplier which can result in a more effective contribution are all strategic factors in NPD (van Echtelt et al., 2008).

Although much of the literature indicates the benefits of involving suppliers in NPD, there is still no clear consensus on the timing or type of project they should be involved in, as is the case of product development with high technological uncertainty (Johnsen, 2009). The literature explores two basic forms of supplier involvement: the approaches known as gray-box and black-box. While the graybox approach assumes industry and its supplier(s) share responsibilities in the project and develop together, the black-box approach assumes that the supplier is responsible for development following the customer's specifications (Koufteros et al., 2007; Petersen et al., 2005). In the auto industry's gray-box approach, suppliers are responsible only for some functions of the development process, presenting technical solutions for approval to the manufacturer that continuously interacts with the suppliers' engineers (Mello and Marx, 2007). In the black-box approach, the company uses the supplier's engineering knowledge and manpower, while maintaining full control over the vehicle design. Drawing on its base of approved first-tier suppliers, the automaker may have the highest technology at a relatively low cost (Clark and Fujimoto, 1991). 
Even though suppliers play an important role, the relationship between suppliers and car manufacturers is by no means easily managed. Mello and Marx (2007) posit that commercial relations in the Brazilian automobile chain are short-termed due to competition among suppliers and progressive reductions in contract costs. Caputo and Zirpoli (2002) present the results of a survey conducted by Fiat, showing the control exerted by the firm and its clear motivation to promote competition among its suppliers. The Italian car maker is therefore able to control prices and have access to cutting edge technology without the need to develop it. As a result, suppliers involved in the competition for contracts end up meeting the needs of other automakers. In this process, there is a trend clearly identified by Takeishi (2001) to transfer technology and managerial information from one car maker to another, thereby reducing the differences among them. This explains how technology can be readily available to all market players.

The advent of the so-called "modularity" in the second half of the 1990s transformed the relationships between automakers and suppliers (Salerno et al., 2002). In transferring to suppliers the function of providing whole modules or systems - no longer just a few parts - automakers started to be concerned with the product architecture and managing systems integration. Hence a new level appears in the supply chain, defined as 'module supplier' or 'systemist', to designate this new configuration of suppliers.

It is not clear yet whether outsourcing product development tasks implies a dependence relationship between automakers and suppliers. Chanaron (1998) demonstrates that systemists make greater investments in research and development (R\&D) than automakers, pointing to a knowledge concentration within suppliers, thereby suggesting the emergence of automakers dependence on suppliers. This situation could lead to what Fine (1999) defines as an "intel-inside" syndrome. This reasoning sheds new light on make-or-buy decisions regarding the new product R\&D process insofar as automakers could become dependent for capacity or knowledge (Fine and Whitney, 1996).

\section{RESEARCH METHODOLOGY}

Research work started in August 2008 and ended in December of the same year within a research group with 16 researches. A simple question - how was flex-fuel technology developed in Brazil? - was the starting point. Concomitantly with the case studies, various research themes appeared, one of which gave rise to the present article

Two distinct phases marked this research. The first dedicated to the research literature, when political, economic, historical and institutional themes relevant to the flex fuel vehicle development were studied. Several papers were produced dealing with issues such as alternative energy sources and scenarios for the automotive industry. The second stage involved a field research, which selected five companies for the study. The only three suppliers of fuel injection solutions installed in Brazil: Bosch, Delphi and Magneti Marelli and two of the three largest automakers with factories in the country and which pioneered the adoption of flex fuel technology: General Motors and Volkswagen. Professional associations involved with the technology were also interviewed. This way, all the main industrial players in flex fuel introduction were dealt with in the study.

Given the difficulty in obtaining permission to record the interviews, the group assigned to perform them (at least three researches), chose to take notes on paper. The research group did not work with questionnaires. The researches had a list of goals that should be attained on each interview, in other words, what information should be collected. The interviews were thus relaxed and informal, conducted as "structured conversations" until such goals were achieved. After the interviews, within 72 hours, students discussed the content and condensed their notes, producing a narrative in a digital file. This file was then submitted and reviewed by the teacher who accompanied them and only then was shared with the rest of the research group, as background reading for the next meet. In these meetings, the results collected were discussed. From this process emerged the points and interpretations that formed the basis for future interviews.

Interviewees contacted in each of the companies and entities occupy executive positions and were actively involved in flex-fuel technology development and adoption. This varied set of primary data sources allowed for a wide range discussion offering differing points of view. The table below summarizes the conducted interviews.

Several s tudies are favorable to the use of case studies in situations like the one proposed in this work (Eisenhardt, 1989; Eisenhardt and Graebner, 2007; Voss, Tsikritsis and Frohlich, 2002; Yin, 2005). Sum 
up the arguments of the studies cited, the specificity of history, the Brazilian context of alternative fuels, emission regulations and tax laws differ from most of the literature on the subject.share. At that point, competitors try to imitate the Innovator's product. This phase evolves into one where product maturity occurs, and competition imitates the Innovator's products with facsimiles at a lower cost. In the De- cline Phase, consumer demand is reduced, resulting in lowered sales and decreased margins. By this time, more innovative (incremental) replacement products have entered the market and product sales taper off. The final phase (Grave) reflects several overlapping issues, such as product and component reuse/recycle, waste streams, legal liabilities, as well as potential penalties for disposal.

Table 1 - Summary of conducted interviews

\begin{tabular}{|c|c|c|c|}
\hline Sep 12,08 & Magneti Marelli & $3 \mathrm{~h}$ & $\begin{array}{l}\text { Comercial Director, R\&D Director, Head of Experimental } \\
\text { Lab }\end{array}$ \\
\hline Sep 15,08 & União da Indústria de Cana-de-Açúcar & $2 \mathrm{~h}$ & Former executive \\
\hline Oct 03,08 & Bosch & $2 \mathrm{~h}$ & Executive Vice Presidente \\
\hline Oct 16,08 & Volkswagen & $3 \mathrm{~h}$ & Engineering Manager \\
\hline Oct 16,08 & Associação Brasileira de Engenharia Automotiva & $2 \mathrm{~h}$ & President \\
\hline Nov 04,08 & Delphi & $3 \mathrm{~h} 30$ & Head Engineer, Engineering Supervisor \\
\hline Nov 12,08 & Volkswagen & $4 \mathrm{~h}$ & Manufacturing Engineer \\
\hline Nov 26,08 & General Motors & $2 \mathrm{~h} 30$ & Product Engineering Manager \\
\hline Dec 01,08 & Magneti Marelli & $2 \mathrm{~h}$ & $\begin{array}{c}\text { R\&D Director, Systems Manager, Experimental Lab Head, } \\
\text { R\&D Engineer }\end{array}$ \\
\hline Dec 15,08 & General Motors & $1 \mathrm{~h}$ & Product Engineering Manager \\
\hline
\end{tabular}

\section{ANTECEDENTS OF FLEX FUEL TECHNOL- OGY IN BRAZIL}

Brazilian research on biofuel vehicles goes back to 1923, when the "Estação Experimental de Combustível e Minérios" - Minerals and Fuel Experimental Station - began experimenting with ethanol on a Ford Model T (38\% of cachaça in its composition).
With the first oil shock by OPEC (Organization of the Petroleum Exporting Countries), in 1973, it was thought that the addition of ethanol to gasoline would reduce Brazilian dependence on imported oil, then very high. By November, 14, 1975, the government issued a Decree, n. 76.593, instituting the "Programa Nacional do Álcool"- Ethanol National Program or Proálcool, as it became known in the 
country. The main goal was the implementation of a $20 \%$ blend of gasoline and ethanol, known today as E20.

The first adapted vehicles were destined to government experimental fleets. Among the auto makers, Volkswagen was the first to start development in motor conversion to ethanol, with a team of 15 German researchers at its R\&D Center in Brazil. Ford and GM only started their efforts in 1978, while Fiat began sometime between 1977 and 1980 (Dahab and Müller, 1986).

At November 1978, there came the Iranian Revolution. Next year, successive oil barrel price raises brought about an oil shortage in the country. The second oil shock brought ethanol to a "national fuel" status. From then on, ethanol was associated to a significant relief on import oil accounts (Santos, 1985).

According to Dahab and Müller (1986), as result of government pressures, which threatened producers with import liberation and incentives concessions to new entrants (mainly Japanese), the automotive industry started to seriously invest in industrial scale production of ethanol run vehicles. The increase in production also forced the auto parts industry to develop dedicated components and equipment to the new motors. In 1979, Fiat launches its first vehicle powered with the new fuel, soon followed by other car makers. Several R\&D efforts were then created within Brazilian automakers, all focusing on alternative power train technologies. This research on alternative power trains greatly advanced the knowledge on ethanol engines, materials compatibility, and use of plastics, rubbers, devices to detect the $\mathrm{pH}$ of ethanol, cold start ignition, among others. This new type of vehicle required the development of a new engine, with a higher compression ratio than gasoline-powered ones, and also demanded the development of new corrosion-resistant materials, applied to several car parts.

Effective sales of hydrated ethanol cars were made in 1981. In 1985 and 1986 their production peaked, accounting for 90 percent of all new vehicles traded in the country (Teixeira, 2005). After 1986, the yearly market share of this type of vehicle gradually decreased. The low internal price of ethanol and the attractive prices in the international sugar market boosted cane conversion to sugar exports, thereby depleting the domestic ethanol market.
Nevertheless, as a consequence of all these developments, all Brazilian gas stations now had two kinds of pumps: some for hydrated ethanol and others for the current mix of gasoline and ethanol (the sanctioned proportion may vary from year to year following market conditions). Of course, all distribution companies also dealt with both fuels. So the distribution infrastructure has been created and maintained, since there remained an aging fleet of ethanol fueled cars.

In May 1986 Brazil's Motor Vehicle Air Pollution Control Program (PROCONVE) was created. This resolution set forth the basic guidelines of the program and the first limits of emission.

\section{FLEX FUEL TECHNOLOGY IN BRAZIL}

Flex or dual fuel is the name given to the technology that allows vehicles to use gasoline, ethanol or any proportion of the mixture of both. The functional principle of dual or flex-fuel injection is the constant electronic monitoring of several variables of the engine (throttle position, pressure and temperature in the intake manifold, engine speed, injection duration, oxygen concentration in the exhaust gases, among various others), which are processed by a central computer and a specific software program that command engine operation for each condition of use.

The great challenge for flex-fuel injection compared to either gasoline (E25, the standard gasoline blend sold in Brazilian service stations) or hydrate ethanol ( $5 \%$ water content) injection is to quickly detect and adjust the engine at each change in the gasoline-ethanol blend. The solution adopted for flex-fuel injection developed by Bosch in the United States used a capacitive sensor installed in the engine's fuel delivery system which detected the gasoline-ethanol ratio before combustion.

Thanks to its know-how in ethanol use, Brazil emerged as a potential market for the new system. In 1992, Bosch made an attempt to introduce flex fuel technology in the country, to no avail. Although some positive results have been achieved (Castro et al., 1994), the high cost of the sensor made the adoption of this system unfeasible in the country. But, at the time, Bosch identified an alternative injection solution: a system that dispensed with the capacitive sensor, but which, according to the tests conducted by the company, resulted in inferior performance (Castro et al., 1994). Nevertheless, the learning from the ethanol experience, the environmental issues 
raised in the Conference on Environment and Development (ECO-1992), held in Rio de Janeiro, and the new goals for emissions determined by the Brazilian government supported the continuation of the research on the flex-fuel solution.

With its accumulated experience in the development of electronic injection in the country, the Magneti Marelli group (MM), the Brazilian subsidiary of the Italian company, began to experiment, in 1998, with a flex-fuel solution that dispensed with the capacitive sensor in the fuel feeding line: the detection of the gasoline-ethanol ratio would occur after the burning of the fuel, through an oxygen sensor (also called lambda sensor) fitted to the exhaust pipe. This so called lambda sensor is a standard component in all electronic injection system using three-way catalysts. That required a significant improvement in the intelligence of the software inserted in the ECU Electronic Control Unit.

At around the same time, Delphi Corporation (Nascimento et al., 2009b) developed a more robust and flexible electronic injection system, aimed at supporting greater variations in the composition of the gasoline ethanol mix. During this process, Delphi devised a flex-fuel solution similar to Magnet Marelli's.

Technical discussions on flex-fuel started to gain momentum in professional associations such as the Brazilian chapter of the Society of Automotive Engineers (SAE Brazil). In March 2000, the Institute for Technological Research (IPT), a São Paulo state owned R\&D institution, organized a seminar on flex-fuel technologies. The event was a landmark for flex-fuel technology and served to raise awareness among automakers and suppliers of dual fuel cars potential. For example, Magneti Marelli Brazil started, in 1998, an unofficial R\&D project in flexfuel technology and its engineers were eager to participate in the event, in order to check the state-ofthe-art.

At 2001, suppliers already have presented the technology to the major car makers in the country. The consolidation of the flex-fuel system without capacitive sensor occurred in this same year, according to the information collected by this research. Apparently, Bosch had to abandon its system with the capacitive sensor and adopt the architecture based on the lambda sensor.
This flex-fuel control solution required a significant improvement of the software "intelligence" that manages all the engine variables. The flex-fuel injection software required extensive changes and had approximately $20 \%$ more code lines related to learning algorithms that adjust the engine to operate in any situation not tested in the lab.

At 2002, the expected launch of flex-fuel technology engines led the automobile supply chain to bring pressure on environment protection agencies in charge of the engines emissions regulations and control. São Paulo State's Pollution Control Company (CETESB) led this initiative with the participation of automakers and suppliers. At November 2002, the federal government enacted a regulation on the emissions for engines equipped with the flexfuel technology. In parallel, negotiations between automakers and federal government evolved to an agreement that extended to flex-fuel cars tax benefits already given to ethanol-powered cars.

The stage was prepared for the launch of flex-fuel engines. A number of car makers were working hard to retool the production line to launch cars with this new technology. The race to define the first launch of a flex-fuel model in Brazil had started.

\section{DEVELOPMENT AT VOLKSWAGEN}

Thanks to the technology brought from the United States by Bosch, VW Brazil had become acquainted with flex-fuel technology in the early 1990s. Nevertheless, the domestic ethanol crisis and the government's tax reduction incentive for cars with engine displacement below one liter made any attempt to develop this technology commercially and economically unfeasible. Even after the advent of the ECO 92, the possibility of using alternative fuels was not yet feasible due to the high cost of the technology offered by Bosch.

Around the early 2000s, environmental conservation efforts like the initiative towards renewable energy, allied with the stabilization of ethanol prices at more competitive levels than those of gasoline, triggered the demand for ethanol cars. Adding to this scenario was the fall of sugar prices on the international market. Lower ethanol prices revived discussions about launching an ethanol car, in the cheaper one liter engine displacement version.

Aimed at forging a partnership with VW to share the costs of developing a flex car in Brazil, Bosch 
again offered its flex-fuel technology (with capacitive sensors) during this period, to no avail.

Pressures were strong and growing at VW Brazil. Results gathered through its marketing clinics identified that customers liked ethanol cars and recognized as positive the fact that it was a Brazilian product, although they feared lack of fuel. The idea of flex engines started to take shape.

In search of cheaper technologies, VW consulted with its supply chain. The engine changes required for the adoption of the new technology forced the automaker to coordinate with other suppliers to implement adaptations. Thus, around 2001, key suppliers were called in for the flex-fuel car project, among them MM. One of the respondents in this research referred to this strategy as a common supply chain policy in the company, aimed at decreasing dependence on suppliers. MM was chosen to develop the flex-fuel technology for engines in the Gol family, since these engines were installed with MM's electronic injection system. VW designated Bosch to develop flex-fuel system for the Polo family.

In 2001, the planning manager presented the flex fuel technology at the Company's Executive Committee meeting (Comex). This plan had been devised based on analyses and results from tests conducted by VW's engineers together with suppliers. That was a delicate moment for the company. There were restrictions on investment and pressures for cost reductions. The issue was eventually discussed in Germany to obtain the necessary approval for the required investments. The project was approved under the assumption that cars would already were assured of an IPI tax reduction. In fact, however, this reduction only occurred after the approval by the VW headquarters.

VW analyzed the possibility of launching the flexfuel technology in one of two engines: EA827 and EA111. The choice fell on the EA827 because it was an engine at 1.6 liters used in the Gol line and have been adapted for ethanol. Production would occur under the "black-box" system, with the MM solution, since VW has no in house expertise in electronic injection. The other option would be launching the flex-fuel technology with the Polo, but because it was a world-class car, internal implications within VW could increase the time-to-market, and VW Brazil decided to abandon this possibility.
The process involved in choosing $\mathrm{MM}$, however, was laden with uncertainly. The technology offered by Bosch, despite its higher cost, had already reached some maturity in the United States, whereas the MM solution was a novelty, not yet market tested. This final decision was delayed until 2002, when VW Brazil challenged MM to demonstrate that its flex-fuel technology could satisfy a 15-question questionnaire prepared by VW's engineering departments. It aimed at resolving any remaining doubts about the reliability of the new architecture. MM accepted the challenge and provided satisfactory technical answers for all 15 questions. In August 2002, VW and MM signed the contract, and the production process was scheduled to start in March of the following year. The flex vehicle launch date was set to March 23 2003, the company's fiftieth anniversary in Brazil.

In the launch year, VW's pioneering efforts led the company's market share of flex-fuel vehicles in Brazil to reach 63 percent, with 30 thousand units sold. Battered by competition in following year, VW market share declines to 41 percent. Along the years, growing adoption of flex-fuel from other car makers caused this figures to drop even more. At the end of 2009, when flex fuel already held 90\% market share, the company had a 25 percent flex-fuel market share, with a little over 680 thousand units sold.

\section{DEVELOPMENT AT GENERAL MOTORS}

The technology for ethanol engines also enabled GM to think about flex-fuel technology. In 1992 GM held informal conversations with its suppliers of electronic injection systems, Delphi and Bosch. Nevertheless, the ethanol supply crisis of the period played down expectations of immediate joint actions. Even more concrete actions could not convince GM to bet on the solution. In 1994, Bosch had installed its capacitive sensor system in a GM vehicle of its own property, an Omega with 2.0 liters engine. The vehicle was road tested, running about 400 thousand kilometers until it was disassembled over 1998-1999 in order to analyze all key components. Results were shared with GM's engineering team. Despite a number of satisfactory results, the high cost of the fuel mix capacitive sensor at the time made the project unfeasible.

Around the year 2000, Brazil witnessed another fall in ethanol prices, along with new government incentives for the acquisition of ethanol vehicles. GM's 
interest returned to flex fuel cars and, according to one respondent of this research, a seminar held in São Paulo at the Institute for Technological Research (IPT) was a landmark. GM brought an ethanol car to this seminar. At the event, asked by one of the participants why GM did not produce more of those vehicles, the respondent justified saying that the problem was the lack of demand. GM still rereleased two ethanol models, which were not sold at a quantity that allowed the continuity of these models. Bosch, by its turn, presented a prototype with the capacitive sensor.

Still in 2000, there began a return to the idea of using the Lambda sensor to detect the fuel composition, an insight which, in the respondent's view, had been concomitantly shared by all systemists involved in this development.

Concomitantly, GM's executives realized that the flex technology could finally bear fruit. GM's flex project was officially started around 2001, in parallel with two suppliers, Bosch and Delphi and it practically involved the entire company.

Discussions were initiated in product planning, but soon involved the departments of engine engineering, vehicle engineering, manufacturing, marketing, sales, services (documentation, handbooks, training of car dealers), governmental relations, and quality.

The time span between project start up and launch of the first vehicle (2001 to 2003) is justified, in the respondent's view, by the extended process involved in developing the solution (calibrations, design of components, etc), the necessary interaction amongst all departments described and also the certifications from emission control agencies. According to the respondent, this process took several months.

The engine chosen for the launch was the one with 1.8 liters of displacement, because they were available in most of GM's product lines and, for marketing reasons, the car model selected was the Corsa. Delphi was the supplier of the electronic injection system for the car and engine chosen. It also used its knowledge of electronic injection systems as a basis for its development of flex-fuel systems. Nevertheless, our respondent emphasizes that when a supplier begins a development, other suppliers will also be involved so as to reduce the company's dependence on them. The respondent also clarified that suppliers exchange information among themselves and that automakers' engineers usually migrate from one company to another, and that this disseminates knowledge. In his words: "People talk with each other. They all know what each other is doing. The only way to prevent this is through an exclusivity contract, which is very rare".

GM defended the idea of gray-box in the development of the flex project. The company created a few algorithms to be incorporated into the suppliers' software and participated in calibrations. Suppliers were in charge of producing the components and the software.

Communications among the project's teams occurred on a daily basis, through personal contacts, over the phone, e-mail and other types of communication, like MSN services. Nowadays the suppliers involved in this project still have resident application engineers interacting with part of GM's team (today comprising 180 engineers). GM also schedules a weekly meeting with its suppliers, known as coordination meetings, where all the details of the project are informed and in particular issues deserving attention from the managers of the teams involved.

It is interesting to note that our interview with Delphi shows that its new product development system is very similar to that of GM, even though Delphi was separated from GM almost 10 years ago. Delphi Brazil had to negotiate with its fellow $R \& D$ centers around the world for specific development tasks. Another paper has presented the Delphi case and there it is clear the competence sharing (Nascimento et al., 2009b), perhaps not voluntarily, that accompanied the flex fuel injection system, from which Delphi seems to be one of the main beneficiaries.

\section{DISCUSSION}

Profiting from a more favorable set of conditions to introduce the flex system, VW and GM started to promote the development of dual-fuel vehicles with the technology developed by suppliers like Bosch, Delphi and MM. In analyzing the development histories of these two car makers, the present study shows that both companies employed some similar and some contrasting strategies in their race to launch a flex-fuel vehicle.

The first similar strategy concerns the use of the bargaining power with fuel injection suppliers. VW and GM account for a large volume of the orders, through which they seek to secure access to technology not yet dominated and maintain competitive costs, thanks to the competition that they can trigger 
among suppliers (Zirpoli and Caputo, 2002). Hence, both sought new suppliers that, together with Bosch-holder of the flex-fuel technology with a capacitive sensor-started to develop flex-fuel technology. Whereas VW partnered with MM, GM allied with Delphi because of Delphi's close relations with $\mathrm{GM}$, for historical reasons. Both could ask MM and Delphi for lower prices for the Bosch architecture, a common practice in the sector. However, these new suppliers of flex-fuel technology presented solutions with a different architecture from that developed by Bosch. They probably observed the failure of Bosch's insistence on its capacitive sensor system and started to study new concepts based on its suppression, with a resulting decrease in the cost of the system.

VW and GM did not really expect a great success for the flex fuel car. In the beginning, they saw the flex fuel vehicle as complementing their product lines. Nowhere in their plans did they see the flex fuel car dominating the market in a few years, as in fact happened. So, VW and GM were careful. First, both launched flex fuel cars with a twist. They were designed with a low compression ratio, as near to a gasoline run vehicle as they could and still be regarded as a flex fuel vehicle. It seems they thought this would preserve their gasoline models if flex fuel cars did not take off. Second, they kept open the possibility of working with both suppliers. MM and Bosch in the case of VW and Delphi and Bosch in GM's case. Both delayed their choice of suppliers until very late in development process and later brought Bosch back for other models.

So, it seems that both VW and GM adopted a real option approach to maximize its technological flexibility. By real option, we simply mean Mitchell and Hamilton (1998) view that strategic options must be kept open when managing R\&D. Later, this idea grew into the financial real options approach, rightly criticized by Adrien and Levinthal (2004) for its quantitative emphasis. Quite simply, the point is not to arrive at decisions based on detailed calculation, but rather to invest a little money to keep options open until the situation evolves and clarifies enough to allow for better decisions later on. In VW and GM cases, most of the R\&D effort was transferred to module suppliers, while VW and GM waited first for regulatory and other issues to be solved and then probed the market with their first tentative car models.

A second strategy shared by both companies was the relative freedom the engineering areas enjoyed to explore the new technology, together with suppli- ers. In both cases, suppliers had to initially convince the automakers' engineers before starting a commercial negotiation.

Another strategy shared by VW and GM relates to their monitoring of market evolutions to decide on the perfect timing for the launch of a car. This monitoring was facilitated by the need to regulate the emissions standard by the debate among engineers at SAE Brazil (cooperation among technicians), by a direct follow-up of the market situation and by pressures for a differentiated governmental tax on the new vehicles category. It can be concluded that neither automaker had any difficulty recognizing the importance of flex-fuel, nor, apparently, did either fall victim to organizational inertia. It is worth observing that in choosing to launch flex-fuel technology with the Gol family, an automobile platform produced only in Brazil, VW's Brazilian subsidiary substantially decreased organizational inertia.

A contrast in strategy observed in VW's and GM's performance lies in the degree of the suppliers' involvement in the development of the solution. By opting for a black-box supply source with MM, VW was able to more readily launch a product with flex-fuel technology, significantly reducing both development time in relation to its rival and the company's need to enhance its absorption capacity (Cohen and Levinthal, 1990). With the contract signed with MM in August 2002 and the launch of the car in March 2003, VW was the first company to have a commercial launch of a flex-fuel vehicle. GM, having spent nearly two years on the same development, announced its launch three months later. GM's strategy indicates, however, its intention to internalize the competence to develop software for engine control system.

However, opting for black-box relation with supplier is not enough. In the case of VW Brazil the selection of the right supplier seems to be relevant. MM Brazil was developing the flex-fuel system essentially as a local R\&D project; therefore it has more control over the development process and was able to satisfy the requirements defined by VW Brazil. Whereas, Delphi Brazil was developing the flex-fuel technology in partnership with other Delphi R\&D centers spread around the world. It should be no surprise that this configuration is bound to increase the project lead time.

Specifically concerning the involvement of suppliers in NPD, this research confirms this practice 
relevance in the case of flex-fuel technology. Both VW and GM demonstrated competence in integrating several subsystems with the new flex-fuel technology and at the same enhancing the suppliers' technological capabilities. Furthermore, the flex-fuel case demonstrates the maturity reached by the auto parts industry established in the country, because it was from this sector-not from automakers-that all the motivation for the research and development of the technology sprang.

\section{CONCLUSIONS}

The technological discontinuity caused by the introduction of the electronic injection system in Brazil marked the start of a period of innovations which culminated in the launch of the flex-fuel technology that dominates the Brazilian automobile market today. A flex fuel vehicle allows the consumer to choose the cheaper fuel, gasoline or ethanol, at tank filling time. It thus eliminates uncertainties concerning ethanol supply shortages and unfavorable relative prices evolution.

The introduction of the flex-fuel system was the fruit of a ten-year plus development phase, strongly influenced by internal factors associated with the companies participating in the process, and by external agents. As identified by this research, other than the favorable evolution of ethanol to gasoline prices, four main factors have driven the adoption of the flex-fuel system in the country. These are: Brazil's experiences with the National Ethanol Program and with ethanol oriented electronic injection systems, the price of flex-fuel systems, and tax reductions.

The development history also demonstrates that Bosch's successful experience in the North American market was not enough to convince VW and GM, in the early 1990s, to launch flex-fuel technology in Brazil. Because of high cost and other contextual factors, Bosch was unable to materialize its business goals. So, a "dominant design" in a specific market (USA) does not necessarily imply its dominance in another market (Brazil) (Nascimento et al., 2009a), due to extra-technological factors (Anderson and Tushman, 1990). In this case, favorable conditions in the Brazilian ethanol and fuel markets.

Future research could be conducted to understand the continuation of automakers and suppliers dependence relations, based on their absorption capacity. Because of constant changes in the electronic devices installed in vehicles, the required technological development by suppliers can increase the knowledge dependence on car makers, as defined by Fine and Whitney (1996). The joint development conducted by VW and MM suggests that this trend will have an increased probability. The Fixson and Sako (2001) study concluded that the automobile industry will hardly face a scenario similar to that of the computer industry, which led to the "Intel inside" effect (Fine, 1999). Nevertheless, in a smaller scale with longterm effects, the possible dependence generated by the black-box development system could undermine the automaker's absorption capacity. The company could lose any competitive differential based on design due to its incapacity to develop it and due to replication by rivals hiring the same supplier (Clark and Fujimoto, 1991; Takeishi, 2001).

Betting on another tack, GM's gray-box strategy at first glance seems to make the company more apt to acquire and apply technological knowledge in new products development. However, it remains to be seen whether GM's bet on absorbing knowledge of the embedded technology will be enough to avoid higher development costs and maintain quality visà-vis the solutions developed by suppliers in the market. The cases presented in this research suggest it will not, considering that the knowledge suppliers extracted from electronic injection systems developed to several car makers allows a new technological leap over each automakers' development knowledge and skills.

\section{REFERENCES}

Adner, R \& Levinthal, D. A. (2004). What is not a real option: considering boundaries for the application of real option to business strategy. Academy of Management Review, Jan 2004, 29, 1, pp. 74-85.

Anderson, P. \& Tushman, M. L. (1990). Techological Discontinuites and Dominant Designs: a cyclical model of technological change. Administrative Science Quartely, 35, 4, pp. 604-633.

Caputo, M. \& Zirpoli, F. (2002). Supplier involvement in automotive component design: outsourcing strategies and supply chain management. International Journal of Technology Management, 23, 1/2/3, pp. 129-154.

Castro, A. C.; Koster, C. H \& Franieck, E. K. (1994). Flexible Ethanol Otto Engine Management System in III Congresso e Exposição Internacionais de Tecnologia da Mobilidade, SAE Brasil, São Paulo. 
Chanaron, J. J. (1998). Automobiles: a static technology, a 'waitand-see' industry? International Journal of Technology Management, 17, 7, pp. 595-634.

Clark, K. B. (1989). Project Scope and Project Performance: the effect of parts strategy and supplier involvement on product development. , 35, 10, pp. 1247-1263.

Clark, K. B. \& Fujimoto, T. (1991) Product Development Performance: Strategy, Organizations and Management in the Auto Industry, Boston, MA, Harvard Business School Press.

Cohen, W. M. \& Levinthal, D. A. (1990). Absortive Capacity: a new perspective on learning and innovation. Administrative Science Quartely, 35, 1.

Dahab, S. S. \& Müller, H. (1986). Difusão de novos produtos: o caso do carro a álcool no Brasil. In: XIV Encontro Nacional de Economia. Brasília: ANPEC, pp. 533-559.

Eisenhardt, K. M. (1989). Building Theories from Case Study Research. Academy of Management Review, 14, 4, pp. 532-550.

Eisenhardt, K. M. \& Graebner, M. E. (2007). Theory Building from Cases: Opportunities and Challenges. Academy of Management Journal, 50, 1, pp. 25-32.

Fine, C. H. (1999). Mercados em evolução contínua: conquistando vantagem competitiva num mundo em constante mutação. Rio de Janeiro: Campus.

Fine, C. H. \& Whitney, D. (1996). Is the Make or Buy Decision a Core Competence? IMVP/MIT. Working Paper.

Fixson, S. \& Sako, M. (2001). Modularity in Product Architeture: Will the Auto Industry Follow the Computer industry? IMVP/MIT. Working Paper.

Johnsen, T. E. (2009). Supplier involvement in new product development and innovation: taking stock and looking to the future. Journal of Purchasing \& Supply Management, 15, pp. 187-197.

Koufteros, X. A.; Cheng, T. C. E. \& Lai, K-H. (2007). "Black-box" and "gray-box" supplier integration in product development: antecedents, consequences and the moderating role of firm size. Journal of Operations Management, 25, pp. 847-870.

Mitchell, G. R. \& Hamilton, W. F. (1988). Managing R\&D as a Strategic Option. RET Management 31, 3, May-June, pp. 1522.

Mello, A. M. \& Marx, R. (2007). Innovative Capacity Maintenance by Automakers in a Product Development Outsourcing Scenario The case of VW in Brazil. International Journal of Automotive Technology and Management, 7, pp. 200-215.

Nascimento, P. T. S.; Yu, A. S. O.; Quinello, R.; Russo, R. F. S. M.; Nigro, F. B. E. \& Lima, N. C. (2009a). Exogenous Factors in the Development of Flexible Fuel Cars as a Local Dominant
Technology. Journal of Technology, Management $\mathcal{E}$ Innovation, 4, pp. $110-119$.

Nascimento, P. T. S.; Yu, A. S. O.; Nigro, F. B.; Frederick, B. W. B.; Pethö, S. L. E. \& Marques, J. J. (2009b). Competência Compartilhada na Determinação da Trajetória Tecnológica do Sistema Flex Fuel: o Caso Delphi. Annales del XIII Seminário Latino Ibero-americano de Gestión Tecnológica. Associatión Latino Americana de Gestión Tecnológica. Cartagena de Índias. Colômbia.

Petersen, K. J.; Handfield, R. B. \& Ragatz, G. L. (2005). Supplier integration into new product development: coordinating product, process and supply chain design. Journal of Operations Management, 23, pp. 371-388.

Salerno, M. S.; Marx, R.; Zilbovicius, M; Graziadio, T.; Dias, A. V. C.; Muniz, S. T. G.; Garcia, R. C.; Lima, J. C. S.; Iveson, S.; Hotta, M. A. \& Soares, R. (2002). A nova configuração da cadeia automotiva brasileira. Retrieved 11/17/2008 World Wide Web, http://www.poli.usp.br/pro/cadeia-automotiva.

Santos, M. H. C. (1985). Alcohol as fuel in Brazil: na alternative energy policy and politics. Thesis (PhD) Massachusetts Institute of Technology, Dept. of Political Science.

Sobral, M. C.; Oliva, F. L.; Damasceno, F.; Escalante, M. \& Teixeira, H. J. (2005). Flexfuel Technology - A Brazilian Innovation. In: 14th International Conference on Management of Technology, Viena.

Takeishi, A. (2001). Bridging inter- and intra-firm boundaries: management of supplier involvement in automobile product development. Strategic Management Journal, 22, 5, pp. 403-433.

Teixeira, E. C. (2005). O desenvolvimento da tecnologia Flex-fuel no Brasil. Instituto DNA Brasil.

Van Echtelt, F. E. A.; Wynstra, F.; Van Weele, A. J. \& Duysters, G. (2008). Managing supplier involvement in new product development: a multiple-case study. Journal of Product Innovation Management, 25, pp. 180-201.

Voss, C.; Tsikritsis, N. \& Frohlich, M. (2002). Case Research in Operations Management. International Journal of Operations E Production Management, 22, 2, pp. 195-219.

Yin, R. K. (2005). Estudo de Caso: planejamento e métodos. 3.ed. Porto Alegre: Bookman.

Zirpoli, F. \& Caputo, M. (2002). The nature of buyer-supplier relationships in co-design activities - the Italian auto industry case. International Journal of Operations and Production Management, 22, 12, pp. 1389-1410. 


\section{AUTHOR'S BIOGRAPHY}

Paulo Tromboni de Souza Nascimento is graduated in Electronic Engineer at the ITA (1979), Master of Systems Analysis and Applications at the Instituto Nacional de Pesquisa Aeroespacial (1984) and PhD in Business Administration at USP (1995). He is currently Associate Professor in Business Administration from the USP focuses on academic and professional activities in strategic management of technology, innnovation and operations.

Wilian Gatti Junior is graduated in Business Administration at FECAP(1995) and Master of Business Administration at UniversidaUSP (2010). Currently he is a PhD student in Business Administration at USP and auxiliar professor at the Universidade Anhembi Morumbi and the PUC SP. He has experience in administration acting on the following themes: technological innovation, knowledge management, logistics and SCM.

Abraham Sin Oih Yu is graduated in Aeronautical Engineering at ITA (1970) and doctorate in Philos-
ophy and Master of Science at Stanford University (1983). He is currently Associate Professor at USP and
researcher at IPT. He has experience in Administration with emphasis in Business Administration, act-
ing on the following themes: technological obsolescence,technological innovation and decision analysis.

Francisco Emílio Baccaro Nigro is graduated in Mechanical Engineering at USP (1968), Masters in Mechanical Engineering at USP (1972) and PhD. in Mechanical Engineering at University of Waterloo (1977). He is currently a mechanical engineer at IPT, director of the Institute of Automotive Quality, director of the AEA and Assistant Professor at USP. He has experience in Mechanical Engineering, with emphasis on engines. 